\title{
35. CRETACEOUS PLANKTONIC FORAMINIFERAL BIOSTRATIGRAPHY, LEG 122, EXMOUTH PLATEAU, AUSTRALIA ${ }^{1}$
}

\author{
A.A.H. Wonders ${ }^{2}$
}

\begin{abstract}
An Albian to Maestrichtian planktonic foraminiferal biozonation for the Exmouth Plateau is proposed, based on the detailed analysis of pelagic successions at Sites 761 and 762 and correlation with Site 763 . Twelve zones and two subzones are recognized. The Albian and Cenomanian zones, currently only three, can probably be subdivided into several more. The ranges of the Tethyan index species Globotruncana ventricosa and Globotruncanita elevata are discussed and found to differ from the ones usually given in standard zonal schemes.

The planktonic foraminiferal succession is interpreted as a mid-latitude one in which the Tethyan influence started suddenly in the late Albian and then fluctuated throughout the Late Cretaceous, with a long low-diversity interval during the Campanian to middle Maestrichtian.
\end{abstract}

\section{INTRODUCTION}

Albian and Upper Cretaceous sediments were recovered in generally continuous successions from Ocean Drilling Program (ODP) Leg 122 Holes 761B, 762C, and 763B. Apart from the Cenomanian/Turonian boundary shale, all of the sediments consist mainly of pelagic calcareous components, reflecting deposition well above the carbonate compensation depth (CCD).

The Cretaceous of the Exmouth Plateau provides a complete record of mid-latitude (just over $30^{\circ} \mathrm{S}$; see Galbrun, this volume, chapter 42) planktonic foraminiferal faunas from the Albian onward. These faunas are of interest because such complete successions from the eastern Indian Ocean and the Northwest Shelf of Australia have not been published.

\section{Previous Work}

Published planktonic foraminiferal zonations covering the entire Upper Cretaceous of the Northwest Shelf of Australia have not been previously available. Much work on the subject has been done by industrial micropaleontologists, but this has not led to the existence of a standard zonation in the public domain.

The only properly documented published zonation for part of the column is that of Wright and Apthorpe (1976), which covers the Maestrichtian of the Northwest Shelf between $20^{\circ}$ and $10^{\circ} \mathrm{S}$. Three Maestrichtian zones were recognized: the upper Maestrichtian Abathomphalus mayaroensis Zone, the middle Maestrichtian Globotruncana contusa Zone, and the lower Maestrichtian Globotruncana lapparenti-linneiana Zone. The authors furthermore implied a Globotruncana ventricosa Zone marking the upper Campanian.

Wright and Apthorpe's (1976) zonation was the partial publication of a scheme designed by Wright (unpubl. data, 1973). This zonation was used as a basis to define time slices for the depositional history of the Upper Cretaceous at the Northwest Shelf by Apthorpe (1979). The zones, covering the Albian through Maestrichtian, were numbered $\mathrm{C} 1$ to $\mathrm{C} 13$ and assigned to discrete chronostratigraphic intervals. Zones C11,

\footnotetext{
1 von Rad, U., Haq, B. U., et al., 1992. Proc. ODP, Sci. Results, 122: College Station, TX (Ocean Drilling Program).

2 BP Research Centre, Chertsey Road, Sunbury-on-Thames, TW16 7LN, United Kingdom.
}

C12, and C13 obviously correspond to Wright and Apthorpe's (1976) Maestrichtian zones, but only a chronostratigraphic interpretation and not a biostratigraphic definition was given for the other zones.

Morgan (1980) published the definitions of Zones C1, C2, $\mathrm{C} 3$, and $\mathrm{C} 4$ as a side issue for the age control of palynostratigraphic biozones. These four zones cover the Albian to Turonian and were essentially defined by the total ranges of Planomalina buxtorfi $(\mathrm{C} 2)$ and Globotruncana $(=$ Helvetoglobotruncana) helvetica (C4). The base of Zone $\mathrm{C} 1$ was ill defined as the base of abundant Hedbergella spp. Morgan referred to Wright's zonation as an unpublished zonation in the BOC Goodwyn RDH 1 Completion Report (1972).

The present author had access to the aforementioned Completion Report, which is not in the public domain. The available version does not contain a formal description of the planktonic foraminiferal zones, although the definitions can readily be implied from Wright's discussion of the biostratigraphically defined intervals. Technically, it would have been possible to correlate the biozonation proposed here for Leg 122 with Wright's C-zonation, but it is preferable to do so separately because of the necessity to obtain authorization from the relevant petroleum companies.

Relevant information from previous deep-sea drilling in the eastern Indian Ocean (Deep Sea Drilling Project Legs 26 and 27) is rather scanty. Herb (1974) described the fragmentary record of Cretaceous planktonic foraminifers from Leg 26. Poor assemblages dominated by hedbergellid forms were recorded from the Albian, Cenomanian, and Turonian. Distinct dicarinellid and marginotruncanid assemblages from the Coniacian and Santonian clearly indicate the Tethyan influence at Site 258 during those stages, about $15^{\circ}$ of latitude south of the Exmouth Plateau. No younger faunas were reported. Krasheninnikov (1974) recorded the planktonic foraminifers from Leg 27. Only the Albian at Sites 259 and 260 yielded significant assemblages; these were entirely hedbergellid. Late Cretaceous faunas were seen only in reworked mixed assemblages at Site 260. Most of the Upper Cretaceous of Leg 27 consists of noncalcareous, zeolitic clays apparently deposited below the CCD.

In a still wider context, the work of Huber (1990) on the Maestrichtian of the Weddell Sea (Leg 113) should be mentioned. This author reported a marked increase in Tethyan influence in the upper Maestrichtian, accompanied, rather para- 


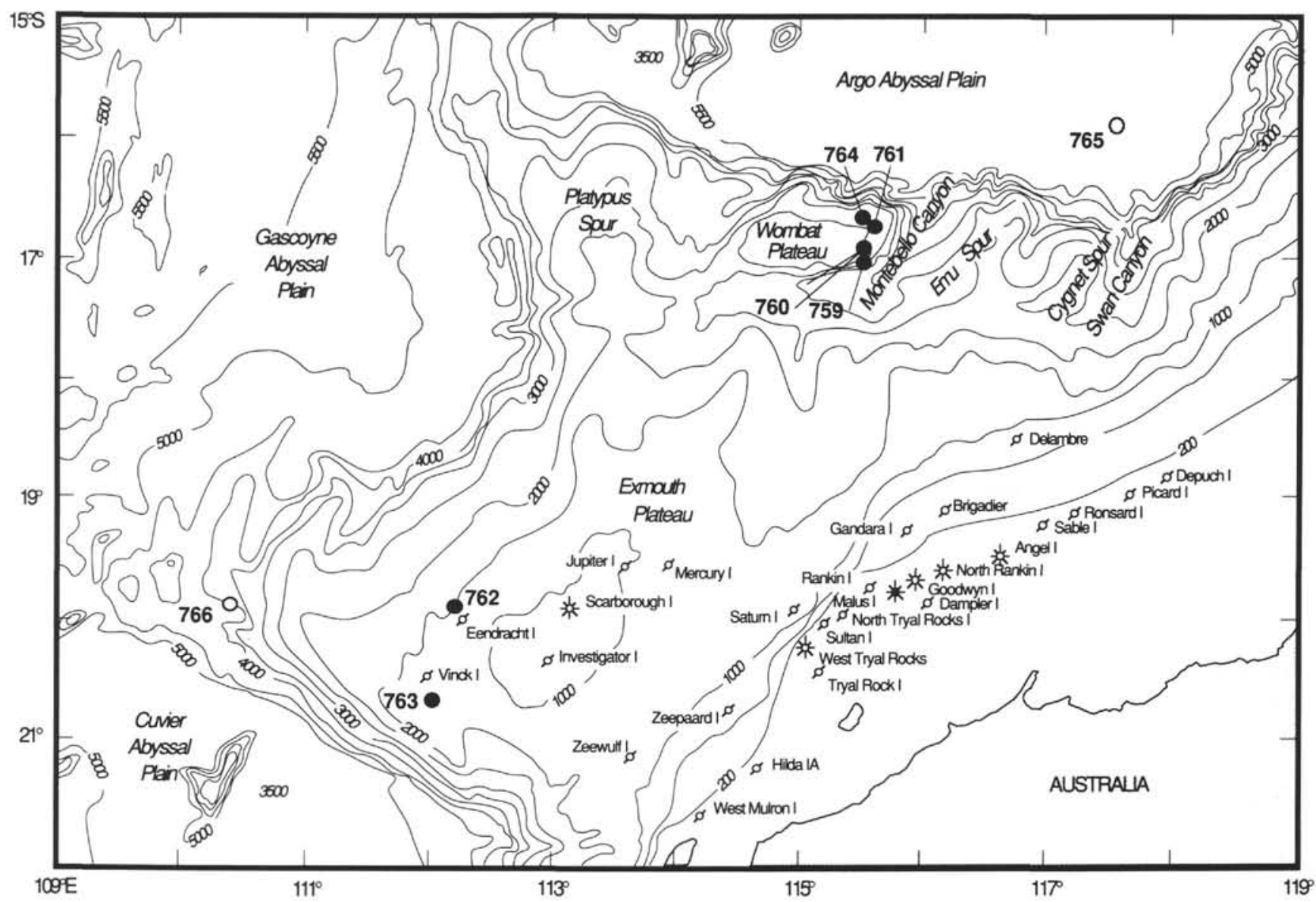

Figure 1. Location map of the Exmouth Plateau ODP sites and commercial well sites (indicated by standard industry symbols). Note the position of well Goodwyn 1 (see text). Bathymetry in meters.

doxically, by a trend toward heavier oxygen isotope values in both benthic and planktonic foraminifers, suggesting cooling. Huber's zonation of the Weddell Sea Maestrichtian was not directly correlated with the one proposed here, as his publication appeared during the final stages of preparation of this paper.

\section{Material Studied}

This study presents the distribution of the most important taxa in two reference sections, Holes 761B and 762C (for locations see Fig. 1). A complete list of the samples investigated is in the Appendix. The biostratigraphic intervals defined in these two holes were correlated to Hole 763B without detailed logging of taxa in order to arrive at a complete biostratigraphic picture for Leg 122 .

\section{Scope of Study}

The primary objective of this study was to define a planktonic foraminiferal biozonation for the Cretaceous at the Exmouth Plateau. Giving an exhaustive record of the occurrences of individual taxa was not attempted, and some groups were deliberately dealt with superficially. The logging of occurrences of taxa was performed according to the principles set out in the "Explanatory Notes" chapter of Haq, von Rad, O'Connell, et al. (1990).

Standard Cretaceous planktonic foraminiferal zonations are already in existence. The unique location of the Exmouth Plateau, extremely remote from any reference section ever used to produce these standard zonations, led the author to use an open-minded approach to the choice of zonal markers. One of the more interesting aspects of the present study was to test the validity of the ranges of classical Tethyan zonal markers in this new area. It has long been suspected, and even known by some, that some markers have rather drastically different ranges on the Northwest Shelf (M. Apthorpe, pers. comm., 1989) and in relatively nearby Papua New Guinea (author's current work).

\section{BIOSTRATIGRAPHY}

\section{Site 761}

At this site, Hole 761B offers a fairly complete Upper Cretaceous section from the upper Maestrichtian Abathomphalus mayaroensis Zone to the Coniacian to upper Turonian Falsotruncana maslakovae Zone. However, only the upper to middle Maestrichtian, which is about $30 \mathrm{~m}$ thick, can be regarded as fully developed; the remainder of the Upper Cretaceous is condensed to about $27 \mathrm{~m}$. As no appreciable increase in clay content was noted in the condensed pelagic facies, it seems most likely that the section contains small hiatuses whose detection is beyond the power of resolution of planktonic foraminiferal biostratigraphy at the sample spacing applied. The strongly condensed lower part of the Upper Cretaceous corresponds roughly to lithostratigraphic Subunit IIB, which is characterized by brownish colors and lamination, as opposed to the much lighter greenish white and white colors of the upper Subunit IIA. 
A summary of the lithostratigraphic, biostratigraphic, and chronostratigraphic units in Hole 761B is given in back-pocket Figure 2, which also contains a distribution chart.

\section{Site 762}

Site 762 offers the most complete Upper Cretaceous section of pelagic facies ever encountered in deep-sea drilling in the Indian Ocean. Hole $762 \mathrm{C}$ was drilled through almost $270 \mathrm{~m}$ of nannofossil and foraminiferal, chalky pelagic sediments in which no hiatuses could positively be identified. The apparent absence of the Contusotruncana contusa Zone may be due to the poor preservation of the planktonic foraminifers or the indurated character of the Maestrichtian chalk at the interval where it was expected; all other zones are present. The Heterohelix rajagopalani Zone and the Globotruncana arca Zone are developed mostly in alternating white, pink, and brown chalks making up lithostratigraphic Subunit IVB, which is sandwiched between the white to greenish Subunits IVA and IVC. Comparison with Site 761 shows that color apparently is not a reliable guide to identifying the condensed section. However, the brown and greenish alternations seen below the Marginotruncana spp. Zone (Subunit IVD) do indicate a condensed section containing all of the Coniacian to upper Albian zones from the $F$. maslakovae Zone to the Planomalina buxtorfi Zone.

A summary of the lithostratigraphic, biostratigraphic, and chronostratigraphic units of Hole $762 \mathrm{C}$ is given in back-pocket Figure 3, which also contains a distribution chart.

\section{Site 763}

In Hole 763B, the top of the Upper Cretaceous is truncated by an erosional unconformity, below which a complete succession of zones was recognized. The youngest chalks below the unconformity belong to the $G$. arca Zone; according to the calcareous nannofossil data this zone covers most of the Campanian. Because Dicarinella asymetrica is very rare in this hole, the Santonian could not be subdivided. The Campanian and Santonian together appear to form a complete pelagic section with no hiatuses or appreciable condensation, although the Santonian must have been deposited at a somewhat slower rate than the Campanian. This interval contains lithostratigraphic Subunits IIIA and IIIB, which are both characterized by white, gray, and greenish colors; brown and pink chalks were not seen. The $F$. maslakovae Zone to the Whiteinella archaeocretacea Zone (Coniacian to lower Turonian) corresponds to lithostratigraphic Subunit IIIC, which is composed of darker gray and green chalks, probably reflecting a degree of condensation of the section with increased clay content. Brown and pink colors were not seen, unlike in Hole 762C. A conspicuous carbonate-poor dark band marks the approximate position of the Cenomanian/Turonian boundary. As no planktonic foraminifers appear to be preserved in and immediately below this bed, it is impossible to decide whether or not it is in the potential range of Rotalipora spp.; by the definition of the local zones, however, the boundary bed falls within the W. archaeocretacea Zone.

The Rotalipora spp. to Hedbergella planispira Zones (Cenomanian and Albian) are relatively thick with a high (more than $50 \%$ ) clay mineral content except near the top, where it still is some $30 \%$. The relatively great thickness (compared with the overlying unit but not with the Campanian) in combination with the relatively high clay content suggests a slightly higher terrigenous supply rather than low carbonate production to account for the peculiar lithology.

A summary of the lithostratigraphic, biostratigraphic, and chronostratigraphic units of Hole 763B is given in back-pocket Figure 4.

\section{Biozonation}

The proposed biozonation is described in the following. The zones are local biozones defined by local bioevents. Ages given are based on literature data and supportive evidence from calcareous nannofossil biostratigraphy (Bralower, this volume).

\section{Abathomphalus mayaroensis Zone}

Definition. From the terminal Cretaceous extinction event to the last downhole occurrence (LDO) of the zonal marker.

Assemblage characteristics. The faunas are dominated by Heterohelix spp. (including $H$. rajagopalani) and Rugoglobigerina spp., but there are fairly consistent occurrences of the zonal marker, G. arca, Pseudotextularia elegans, Racemiguembelina fructicosa, and Gublerina cuvillieri. Toward the top of the zone, $C$. contusa is common. Representatives of the Globotruncana rosetta group (e.g., G. falsostuarti, G. dupeublei) occur sporadically. Single-keeled forms (Globotruncanita stuarti, $G$. angulata) are extremely rare.

It would appear that the faunas of the A. mayaroensis Zone are particularly diverse toward the top. However, the entire zone is characterized by more consistent occurrences of keeled globotruncaniids than the underlying zone.

Age. Late Maestrichtian.

\section{Contusotruncana contusa Zone}

Definition. From the LDO of A. mayaroensis to the LDO of the zonal marker.

Assemblage characteristics. Essentially as above, but without $A$. mayaroensis. G. arca is common to abundant. The range of Abathomphalus intermedius defines a subzone in the upper part of the zone. The base of the zone coincides with a downhole drop in diversity, below which no representatives of the genus Contusotruncana are found in the adjacent zone. It is suspected that the base of the zone is locally defined by immigration, rather than evolutionary appearance, of $C$. contusa.

Age. Middle Maestrichtian.

\section{Heterohelix rajagopalani Zone}

Definition. From the LDO of $C$. contusa to the LDO of the zonal marker.

Assemblage characteristics. Together with the underlying zone, the $H$. rajagopalani Zone forms a low-diversity interval dominated by Rugoglobigerina rugosa, Rugoglobigerina milamensis, G. arca, Globigerinelloides spp. (in the lower part in Hole 762C), and Heterohelix spp., and Pseudotextularia nutalli (PI. 2, Figs. 2, 3) rather than $P$. elegans. Globotruncana linneiana (PI. 1, Figs. 2,3) is present fairly consistently in low numbers. The presence of the zonal marker is the only reliable biostratigraphic criterion for distinguishing the zone from the $G$. arca Zone, although several secondary criteria may be used successfully, for example, the virtual absence of Globotruncana bulloides and the presence of $R$. milamensis and Globotruncanella navensis (PI. 2, Fig. 4a-c).

Age. Early Maestrichtian to late Campanian. This age assignment is based on the age of the first appearance of $H$. rajagopalani within the Globotruncanita calcarata Zone as given by Nederbragt (1990).

\section{Globotruncana arca Zone}

Definition. From the first-appearance datum of $H$. rajagopalani to the first downhole occurrence (FDO) of $D$. asymetrica.

Assemblage characteristics. As above, but without $H$. rajagopalani and with sporadic occurrences of Contusotruncana fornicata. $G$. bulloides (PI. 3, Figs. 1, 2) is common in the upper part, and Globotruncanita (e.g., G. stuartiformis [P1. 3, Figs. 5, 6]) occurs in very low numbers in the lower part. Globotruncana ventricosa occurs regularly except toward the top of the zone. $R$. rugosa becomes a dominant species only in the upper part of the zone; farther down the assemblages are dominated by small heterohelicids (mainly $\mathrm{H}$. globulosa) and Globigerinelloides spp. There is a slight overall decrease in diversity from the lower part of the zone upward.

Near the bottom of the zone, several species of Marginotruncana (M. coronata, $M$. sinuosa, $M$. undulata) are present, but not $D$. asymetrica and Hedbergella flandrini. This assemblage is thought to define a basal Campanian $M$. coronata Subzone.

Age. Late late Campanian to early Campanian. 


\section{Dicarinella asymetrica Zone}

Definition. Total range of the zonal marker; the FDO of $H$. flandrini may be used as an alternative to define the top.

Assemblage characteristics. This zone is characterized by rich and diverse assemblages of Marginotruncana spp. ( $M$. coronata, $M$. undulata, $M$. sinuosa, $M$. pseudolinneiana [Pl. 3, Figs. 7, 8], and $M$. tarfayensis), Hedbergella flandrini, and the zonal marker. G. ventricosa, Globotruncana linneiana, and Globotruncanita elevata range throughout the zone but do not occur in every sample.

Age. Late Santonian.

\section{Marginotruncana spp. Zone}

Definition. From the LDO of $D$. asymetrica to the FDO of $F$. maslakovae.

Assemblage characteristics. Essentially as above, but without $D$. asymetrica. Dicarinella concavata may be found sporadically but is too rare to be used as a zonal marker. $W$. archaeocretacea and Dicarinella imbricata are present near the base of the zone and may be taken to indicate the vicinity of the Santonian/Coniacian boundary. However, D. imbricata was not used as a zonal marker because of its wide variability in morphology, ranging from the typical Dicarinellatype with depressed ventral sutures to a Marginotruncana-type (PI. 4, Fig. 1a-c; Pl. 5, Fig. 1a-c) with $U$-shaped raised ventral sutures.

Age. Early Santonian to late Coniacian.

\section{Falsotruncana maslakovae Zone}

Definition. From the FDO of the zonal marker to the FDO of $H$. helvetica.

Assemblage characteristics. The zonal marker is consistently present throughout the zone, except perhaps at the very base. The Marginotruncana spp. fauna is essentially as in the overlying zone, but there are no Globotruncana and Globotruncanita spp. in this zone; $D$. imbricata and $W$. archaeocretacea are particularly characteristic but cannot be used to define the zone as they also occur immediately below and above. Ventroconvex single-keeled forms in this zone belong to Marginotruncana marianosi (PI. 4, Figs. 5, 6); they are quite variable in morphology and can be confused with the younger $G$. elevata and the older $H$. helvetica.

Age. Coniacian to late Turonian.

\section{Helvetoglobotruncana helvetica Zone}

Definition. Total range of the zonal marker.

Assemblage characteristics. The zonal marker is the most characteristic form in this zone, which is furthermore characterized by the genera Dicarinella, Praeglobotruncana, and Whiteinella.

Age. Middle Turonian.

\section{Whiteinella archaeocretacea Zone}

Definition. From the LDO of $H$. helvetica to the FDO of Rotalipora. Assemblage characteristics. This is a typical interval zone characterized by the absence, rather than by the presence, of characteristic forms. Most abundant is W. archaeocretacea. In our material, we found Praeglobotruncana gibba, Dicarinella hagni (PI. 5, Figs. 2, 3), and D. imbricata in addition, but none of these can be considered as restricted to the zone.

Age. Early Turonian (to late Cenomanian?),

\section{Rotalipora spp. Zone}

Definition. From the FDO of Rotalipora to the FDO of $P$. buxtorfi.

Assemblage characteristics. Strongly ventroconvex Rotalipora s.l. (Thalmanninella deeckei, Th. reicheli, Th. brotzeni), Rotalipora cushmani, and Praeglobotruncana spp., accompanied by Hedbergella spp., are the typical forms of this broad zone. Not enough samples have been studied to clearly unravel the local ranges of the individual taxa. From a paleoenvironmental point of view it is interesting to note that the genus Favusella (e.g., F. washitensis) was not found in any of the samples.

Age. Cenomanian.

\section{Planomalina buxtorfi Zone}

Definition. Total range of the zonal marker.

Assemblage characteristics. Unlike in truly Tethyan faunas, $P$. buxtorf is commonly the only keeled form, only rarely accompanied by rotaliporids. Scattered Praeglobotruncana delrioensis and common Hedbergella spp. are more characteristic. P. buxtorfi itself is rather peculiar, represented by a double-keeled variety that tends to be the dominant form.

Age. Late Albian.

\section{Hedbergella planispira Zone}

Definition. This zone has abundant occurrences of the zonal marker below the LDO of $P$. buxtorfi. A strict definition is not given here in order to avoid zonal terminology in the future.

Assemblage characteristics. The assemblages in this zone are virtually monospecific, consisting of superabundant $H$. planispira. A poor Tethyan influence is indicated by the absence of Ticinella spp. and of Biticinella breggiensis.

Age. Albian, as far as ascertained.

\section{NOTES ON INDEX TAXA}

The biostratigraphically most important taxa of this paper are briefly discussed in the following.

\section{Abathomphalus intermedius (Bolli)}

Globotruncana intermedia Bolli, 1951, p. 197, pl. 35, figs. 7-9.

\section{Abathomphalus mayaroensis (Bolli)}

Globotruncana mayaroensis Bolli, 1951, p. 198, pl. 35, figs. 10-12. Abathomphalus mayaroensis (Bolli), Bolli et al., 1957, p. 43, pl. 11, fig. 1a-c; Wright and Apthorpe, 1976, p. 240, pl. 2, figs. 13, 14.

Remarks. On the Exmouth Plateau, the range of $A$. mayaroensis appears to be defined by its evolutionary appearance from $A$. intermedius and its extinction at or very near the Cretaceous/Tertiary boundary. Therefore, the $A$. mayaroensis Zone most probably has the same chronostratigraphic significance as elsewhere.

\section{Contusotruncana contusa (Cushman)}

Pulvinulina arca Cushman var. contusa Cushman, 1926, p. 23.

Globotruncana arca (Cushman) var. contusa Cushman, Cushman, 1946 , pl. 62, fig. 6a-c.

Globotruncana contusa (Cushman), Wright and Apthorpe, 1976, p. 239, pl. 1, figs. 9, 10

Rosita contusa (Cushman), Robaszynski et al., 1984, p. 246, pl. 36, figs. 1,2 ; pl. 37 , figs. $1-3$.

Contusotruncana contusa (Cushman), Korchagin, 1982, p. 119.

Remarks. $C$. contusa appears just below the $A$. mayaroensis Zone in Hole $761 \mathrm{~B}$ and together with A. mayaroensis in Hole 762C. It is suspected that these initial appearances are environmentally controlled and that the potential range of the species is longer than that apparent on the Exmouth Plateau. Apthorpe (1979) used the frequent absence of Zone C12 ( $C$. contusa Zone) as evidence of a regional hiatus on the shallower part of the Northwest Shelf. However, on the Exmouth Plateau the calcareous nannofossil biostratigraphy does not support a hiatus as a cause for the virtual absence below the $A$. mayaroensis Zone (see Bralower, this volume).

\section{Dicarinella asymetrica (Sigal)}

Globotruncana asymetrica Sigal, 1952, p. 35, fig. 35 .

Dicarinella asymetrica (Sigal), Robaszynski and Caron, 1979, p. 61, pl. 51, fig. 1a-c.

Remarks. This species is an important marker in the upper Santonian of the Exmouth Plateau. It is quite rare, however, and we have used Hedbergella flandrini, where occurring above D. asymetrica, as alternative evidence of the presence of the $D$. asymetrica Zone. It is important to avoid confusing D. asymetrica with Globotruncana ventricosa, as the two species occur together in the Santonian.

\section{Dicarinella concavata (Brotzen)}

Globotruncana (Globotruncana) ventricosa ventricosa White, Dalbiez, 1955, p. 168, text-fig. 7a-d.

Marginotruncana concavata (Brotzen) "sensu Dalbiez, 1955," Wonders, 1980, p. 123, pl. 5, fig. 2a-c.

Remarks. It is suspected that the lectotype designated by Kuhry (1970) is a juvenile $D$. asymetrica. If this is so, complex taxonomic 
problems arise from the ensuing synonymies. Therefore, the species concept within the group of $D$. concavata as applied by Dalbiez (1955) is adhered to here, with reference to the discussion of the problem by Wonders (1980). It suffices here to note that Dalbiez (1955) described the members of the $D$. concavata lineage as subspecies of $G$. ventricosa, which unfortunately adds to the taxonomic confusion.

D. concavata is extremely rare in our material and could not be used as a zonal marker.

\section{Falsotruncana maslakovae Caron}

(Pl. 4, Figs. 3a-c, $4 a-c)$

Falsotruncana maslakovae Caron, 1981, p. 67, pl. 2, fig. 1a-d.

Remarks. $F$. maslakovae is consistently present in the $F$. maslakovae Zone, except perhaps at the very base. According to Caron (1985), its range starts immediately upon the extinction of $H$. helvetica and its top would be within the Coniacian. Correlation with the calcareous nannofossil biostratigraphy (see Bralower, this volume) suggests that the highest occurrence is close to the top of the Coniacian on the Exmouth Plateau.

Globotruncana arca (Cushman)

(Pl. 1, Fig. 1a-c; Pl. 2, Fig. 1a-c)

Pulvinulina arca Cushman, 1926, p. 23, pl. 3, fig. 1a-c.

Remarks. This species commonly occurs in great numbers, together with abundant $R$. rugosa, in the $G$. arca Zone and the $H$. rajagopalani Zone, and it continues up to the top of the Maestrichtian. There is a rather wide variation in morphology and there may be potential for distinguishing biostratigraphically and paleoecologically significant morphotypes.

\section{Globotruncana ventricosa White}

(PI. 3, Figs. 3a-c, 4a-c)

Globotruncana canaliculata (Reuss) var. ventricosa White, 1928, p. 284 , pl. 38, fig. 3a-c.

Globotruncana sp. aff. ventricosa (White) Herb, 1974, p. 754, pl. 7, figs. 1, 3-5, 8, 9 .

Remarks. The vertical distribution of this species was one of the more surprising results of this study. The range of $G$. ventricosa extends down as far as the lower Santonian on the Exmouth Plateau, and its value as a marker for the upper Campanian (cf. Wonders, 1980; Caron, 1985) must be restricted to the Western Tethys. Wonders (1980) already noted that $G$. ventricosa suddenly appeared, supposedly as an immigrant, in Southern Spain, implying that it must have a longer range elsewhere.

\section{Globotruncanita elevata (Brotzen)}

Rotalia elevata Brotzen, 1934, p. 66, pl. 3, fig. C.

Globotruncana elevata (Brotzen), Kuhry, 1970, p. 292, pl. 1, figs. 1-3.

Remarks. G. elevata occurs rarely in the Campanian but is much more frequent throughout the Santonian. It can easily be confused with $M$. marianosi in the Coniacian to upper Turonian. It is here considered as an unfortunate choice for a marker of the lower Campanian G. elevata Zone (cf. Wonders, 1980; Caron, 1985) and therefore was not used as such. The overlap in the ranges of $G$. elevata and D. asymetrica was used to define a brief zone in the upper Santonian by Wonders (1980). This overlap appears to be much longer on the Exmouth Plateau, to the extent that $G$. elevata even appears earlier than $D$. asymetrica. As a consequence, the biostratigraphic value of the species is considerably less than hitherto believed.

\section{Gublerina cuvillieri Kikoine}

(Pl. 1, Figs. 5, 6)

Gublerina cuvillieri Kikoine, 1948, p. 26, pl. 2, fig. 10a-c; Nederbragt, 1990 , p. 86 , pl. 1 , figs. 3,4 .

Not Gublerina cuvillieri Wright and Apthorpe, 1976, p. 238, pl. 1, fig. 1.

Remarks. The range for $G$. cuvillieri as given by Wright and Apthorpe (1976) is almost certainly a combination of the ranges of $G$. cuvillieri and $H$. rajagopalani. Detailed study of the morphology of both species in the middle to upper Maestrichtian may reveal a phylogenetic relationship. In our material, the biserial stage of $G$. cuvillieri resembling $H$. rajagopalani is shorter than that of $H$. rajagopalani. $G$. cuvillieri has a coarser ornamentation and its initial stage is more rounded.

$$
\text { Hedbergella planispira (Tappan) }
$$

Globigerina planispira Tappan, 1940, p. 122, pl. 9, fig. 12a-c.

$$
\text { Helvetoglobotruncana helvetica (Bolli) }
$$$$
\text { (Pl. 4, Fig. 7a-c) }
$$

Globotruncana helvetica Bolli, 1945, p. 226, pl. 9, fig. 6.

\section{Heterohelix rajagopalani (Govindan)}

(Pl. 1, Figs. 7-9; Pl. 2, Figs. 5-13)

Gublerina rajagopalani Govindan, 1972, p. 170, pl. 2, figs. 1-5.

Gublerina cuvillieri Kikoine, Wright and Apthorpe, 1976, p. 328, pl. 1, fig. 1.

Hetrohelix rajagopalani Kikoine, Nederbragt, 1990, p. 96, pl. 4, figs. $1-3$.

\section{Marginotruncana spp}

Remarks. No individual species has been singled out to mark the interval zone between the top of $F$. maslakovae and the base of $D$. asymetrica. The genus is used in the sense of Robaszynski and Caron (1979). In the Marginotruncana spp. Zone and D. asymetrica Zone, common representatives are $M$. coronata, $M$. pseudolinneiana, $M$. sinuosa, and $M$. tarfayensis.

\section{Rotalipora spp.}

Remarks. The genus is used in the sense of Robaszynski and Caron (1979) and includes the genera Pseudothalmanninella, Thalmanninella, and Rotalipora as used by Wonders (1978).

No zonal markers have as yet been selected from the various keeled rotaliporids between the top of the $P$. buxtorf Zone and the base of the $W$. archaeocretacea Zone. More detailed sampling than applied for this study is necessary to arrive at a reliable zonation. On the limited evidence available, it would appear that strongly umbilico-convex morphotypes such as $R$. deeckei and $R$. reicheli are particularly well represented on the Exmouth Plateau, but that these two species are difficult to separate both morphologically and biostratigraphically.

\section{Planomalina buxtorfi (Gandolfi)}

Planulina buxtorfi Gandolfi, 1942, p. 103, fig. 7a-c

Remarks. Most specimens from the Exmouth Plateau have two distinct keels rather than a single keel, and many specimens have an almost circular rather than truncated triangular chamber outline in apertural view. The present author has seen these features in $P$. buxtorfi populations from India and Papua New Guinea and it may in the future be shown that they are characteristic of either Southern mid-latitude or Eastern Tethys faunas.

\section{Rugoglobigerina rugosa (Plummer)}

(Pl. 1, Figs. 10a, 10b; Pl. 2, Figs. 14a-c, 15a-c)

Globigerina rugosa Plummer, 1926, p. 38, pl. 2, fig. 10a.

Archaeoglobigerina australis Huber, 1990, p. 504, pl. 3, figs. 1-7.

Remarks. Most of the abundant Rugoglobigerina occurring in the $G$. arca and $H$. rajagopalani Zones were assigned to this species. In the A. mayaroensis Zone, a much greater variety of species is found, in which the $R$. rugosa morphotype is hardly, if at all, represented. The species is taken in a wide sense in this paper. It is suspected that the morphotypes from the Exmouth Plateau are relatively simple variants of the typical form. They lack distinct costellae, and tegilla were not observed. As such, they conform in detail with Huber's (1990) material from the South Atlantic.

Whiteinella archaeocretacea Pessagno

(PI. 5, Figs. 4a-c, 5a-c, 6a-c, 7a-c)

Whiteinella archaeocretacea Pessagno, 1967, p. 298, pl. 54, figs. 22-24.

Remarks. Morphotypes assigned to this species are particularly common in the interval zone defined by the extinction of Rotalipora and the first appearance of $\boldsymbol{H}$. helvetica. Five-chambered forms predominate. The total range of the species is not clear as it depends largely on the synonymy applied. 


\section{Discussion}

This paper is a first attempt to formalize the Albian to Maestrichtian planktonic foraminiferal record of the Northwest Shelf in a published zonation scheme. The biozonation is bound to be refined considerably in the future and for that purpose much further work is needed.

The proposed zonation reflects the local (or regional) development of planktonic faunas. It was thought inappropriate to try and force the local record into existing schemes, as it was apparent from the start that certain important index species had local ranges that differ from what has been generally accepted. The occurrence throughout the Santonian of G. elevata and $G$. ventricosa, in particular, prevented a rigid application of previously published Tethyan schemes.

The major part of the Albian is characterized by oligotypic $H$. planispira faunas, without any apparent tropical influence in the form of ticinellid and, in the older part of the upper Albian, rotaliporid morphologies. The topmost part of the Albian is represented by the $P$. buxtorf $i$ Zone, reflecting a considerably increased but still marginal Tethyan influence. $P$. buxtorfi is commonly double keeled and therefore atypical; this could be an ecophenotype occurring at the edge of the paleogeographic distribution of the species. Whether the change from high-latitude to marginal Tethyan faunas took place before, during, or after the evolution of $P$. buxtorfi from a nonkeeled ancestor remains to be investigated. The absence, in our material, of Planomalina praebuxtorfi may suggest that $P$. buxtorf is an immigrant on the Exmouth Plateau, but it may also be due to sample spacing.

The Cenomanian, with its rotaliporid species, was a stage with strong Tethyan influence, as most keeled species appear to be present in our material. However, the strongly ventroconvex morphotypes Rotalipora reicheli and $R$. deeckei are particularly common and the relatively flat $R$. appenninica was hardly seen at all. There are also individual samples with strongly impoverished planktonic faunas. To what extent this affects the local ranges of index species has to be established by the analysis of more closely spaced samples.

The Cenomanian/Turonian boundary interval has not yet been studied in detail. It would appear that the genus Rotalipora s.l. disappears just below the dark mudstone layer marking the boundary and that the boundary, at least locally, falls within the $W$. archaeocretacea Zone. The boundary interval shows a marked resemblance to that developed in the classic Tethyan sections, for example, in the Umbrian Apennines in Italy (e.g., Wonders, 1979), with deposition of pelagic clay below a local CCD.

The Turonian and Coniacian stages are represented by fully Tethyan planktonic faunas in which all keeled morphotypes, including the single-keeled genera Helvetoglobotruncana and Marginotruncana, are present. After the extinction of Helvetoglobotruncana, the most characteristic form is $F$. maslakovae, a form that the present author has never seen to occur as commonly and consistently as on the Exmouth Plateau.

The Santonian saw a continuation on the marginotruncanid theme, but the supposedly bathypelagic $D$. concavata group is poorly represented in the lower part. However, the homeomorphic G. ventricosa occurs throughout, and Globotruncanita elevata is present as well. The marginotruncanid faunas survived into the earliest Campanian, until after the extinction of $D$. asymetrica.

Of special biostratigraphic and paleoceanographic interest is a long interval in the Campanian and the lower half of the Maestrichtian with planktonic microfaunas dominated by long-ranging double-keeled globotruncanids (mainly G. arca, with sporadic floods of $G$. bulloides, C. fornicata, and $G$. linneiana), Rugoglobigerina spp., and Heterohelix spp. This interval postdates a virtually fully Tethyan upper Santonian with abundant marginotruncanids, G. elevata, G. ventricosa, and Dicarinella asymetrica; it predates an almost equally Tethyan upper Maestrichtian with rich and diverse globotruncanid and heterohelicid faunas in which only the single-keeled groups (Globotruncanita, Gansserina, and the single-keeled end forms of the G. rosetta lineage) are poorly, if at all, represented. This Campanian-Maestrichtian low-diversity interval shows the weakest Tethyan influence of all the Upper Cretaceous; if Tethyan influence can be seen as a measure of seawater temperature, it certainly would appear to be the coolest interval of the entire time span from the late Albian to late Maestrichtian. However, lack of oceanic stratification due to the presence of relatively warm water at bathypelagic depths may also be an explanation, as could be a relatively short distance to the shore. Apthorpe (1979) convincingly showed that the Campanian was a time of rapid progradation of a carbonate shelf, especially on the northern half of the Northwest Shelf. This may have narrowed the connection with the more northerly situated Tethyan oceanic areas and hampered the development of Tethyan faunas farther south. Finally, the absence of supposedly bathypelagic forms during much of the Campanian and early Maestrichtian could simply be a result of insufficient water depth on the Exmouth Plateau. This, however, would appear to be highly unlikely in view of the age of the onset of postrift subsidence and of present-day water depth. Whatever the explanation, the Campanian-Maestrichtian faunal restriction in the Exmouth Plateau sample material deserves further study.

The $C$. contusa Zone and the A. mayaroensis Zone of the middle and upper Maestrichtian reflect an increased Tethyan influence, but the scarcity of single-keeled planktonic forms still points to some restriction. C. contusa is probably an immigrant on the Northwest Shelf and it remains to be seen when this event took place; it must be assumed that it postdates the evolutionary appearance of $C$. contusa elsewhere, but it predates the evolutionary appearance of Abathomphalus intermedius. According to Apthorpe (1979), the late Maestrichtian was a time of rapid regional transgression on the Northwest Shelf, and this could plead in favor of the importance of the distance-to-shore factor for the diversity of planktonic foraminiferal faunas.

\section{CONCLUSIONS}

The main result of this study is a biozonal scheme that may serve as a basis for further biostratigraphic refinement in the future. Twelve zones, covering the Albian to the Maestrichtian, are recognized. The zonation of the upper Albian and Cenomanian certainly is in need of refinement; this can probably be achieved by closer spaced sampling of the available sections, especially of Hole 763B. Two issues to be addressed are (1) the local ranges of keeled rotaliporids and (2) the presence or absence of a Rotalipora ticinensis Zone between the Planomalina buxtorfi Zone and the Hedbergella planispira Zone.

The zonation of the post-Cenomanian Upper Cretaceous differs from other zonations for several reasons:

1. The Exmouth Plateau planktonic foraminiferal faunas are not truly Tethyan, with especially the Campanian and lower Maestrichtian showing a lack of Tethyan influence. This long interval could be subdivided only by using the heterohelicid species Heterohelix rajagopalani; the older members of the Dicarinella concavata lineage (D. primitiva and D. concavata) are so rare that they cannot be used as zonal markers. Falsotruncana maslakovae was used as a Coniacian to upper 
Turonian marker rather than any of the long-ranging Marginotruncana spp.

2. The ranges of the important Tethyan markers Globotruncanita elevata and Globotruncana ventricosa extend down into the Santonian.

The base of the range of Contusotruncana contusa is controlled by a strong increase in Tethyan influence in the Maestrichtian rather than by the evolutionary appearance of the species.

Further work is also needed to integrate the scheme proposed here with existing but unpublished zonation schemes applied in Northwest Shelf Cretaceous planktonic foraminiferal biostratigraphy.

\section{ACKNOWLEDGMENTS}

The progress of this study benefited from discussions in writing with M. Apthorpe, Perth, Australia. Technical assistance by B.P. Research Centre, Sunbury-on-Thames, and by M. Lawson, Watford, is gratefully acknowleged. I thank the Boards of Directors of B.P. Research and of B.P. Exploration for sponsoring my participation on Leg 122 and for permission to publish this paper.

\section{REFERENCES}

Apthorpe, M., 1979. Depositional history of the Upper Cretaceous of the Northwest Shelf, based upon foraminifera. APEA J., 19:7489.

Bolli, H. M., 1945. Zur Stratigraphie der Oberen Kreide in den höheren helvetischen Decken. Eclogae Geol. Helv., 37:217-329. 1951. The genus Globotruncana in Trinidad, B.W.I. J. Paleontol., 25:187-199.

Bolli, H. M., Loeblich, A. R., Jr., and Tappan, H., 1957. Planktonic foraminiferal families Hantkeninidae, Orbulinidae, Globorotaliidae, and Globotruncanidae. Bull. U.S. Nat. Mus., 215:3-50.

Brotzen, F., 1934. Foraminiferen aus dem Senon Palästinas. Z. Dtsch. Ver. Erforsch. Palästinas, 57:28-72.

Caron, M., 1981. Un nouveau genre de foraminifere planctonique du Crétacé: Falsotruncana nov. gen. Eclogae Geol. Helv., 74:65-73. 1985. Cretaceous planktic foraminifera. In Bolli, H. M., Saunders, J. B., and Perch-Nielsen, K. (Eds.), Plankton Stratigraphy: Cambridge (Cambridge Univ. Press), 713-762.

Cushman, J. A., 1926. Some foraminifera from the Mendez Shale of eastern Mexico. Contrib. Cushman Lab. Foraminiferal Res., 2:16-26.

1946. Upper Cretaceous foraminifera of the Gulf Coastal region of the United States and adjacent areas. Geol. Surv. Prof. Pap. U.S., 206:1-241.

Dalbiez, F., 1955. The genus Globotruncana in Tunisia. Micropaleontology, 1:161-171.

Gandolfi, R., 1946. Richerche micropaleontologiche e stratigrafiche sulla Scaglia e sul Flysch dei dintorni di Balerna. Mem.-Riv. Ital. Paleontol., 4:1-170.

Govindan, A., 1976. Upper Cretaceous planktonic foraminifera from the Pondicherry area, South India. Micropaleontology, 18:170193.

Haq, B. U., von Rad, U., O'Connell, S., et al., 1990. Proc. ODP, Init. Repts., 122: College Station, TX (Ocean Drilling Program).
Herb, R., 1974. Cretaceous planktonic foraminifera from the eastern Indian Ocean. In Davies, T. A., Luyendyk, B. P., et al., Init. Repts. DSDP, 26: Washington (U.S. Govt. Printing Office), 745-770.

Huber, B. T., 1990. Maestrichtian planktonic foraminifer biostratigraphy of the Maud Rise (Weddell Sea, Antarctica): ODP Leg 113 Holes 689B and 690C. In Barker, P. F., Kennett, J. P., et al., Proc. ODP, Sci. Results, 113: College Station, TX (Ocean Drilling Program), 489-513.

Kikoine, J., 1948. Les Heterohelicidae du Crétacé Supérieur pyrénéen. Bull. Geol. Soc. Fr., Ser. 5, 18:15-35.

Korchagin, V. I., 1986. Sistematika Globotrunkanid. Byull. Mosk. Ova. Ispyt. Prir., Otd. Geol., 57:114-161.

Krasheninnikov, V. A., 1974. Cretaceous and Paleogene planktonic foraminifera, Leg 27 of the Deep Sea Drilling Project. In Veevers, J. J., Heirtzler, J. R., et al., Init. Repts. DSDP, 27: Washington (U.S. Govt. Printing Office), 663-671.

Kuhry, B., 1970. Some observations on the type material of Globotruncana elevata (Brotzen) and Globotruncana concavata (Brotzen). Rev. Esp. Micropaleontol., 6:691-304.

Morgan, R., 1980. Palynostratigraphy of the Australian Early and middle Cretaceous. Mem.-Geol. Surv. N.S.W. Palaeontol., 18:1153.

Nederbragt, A. J., 1990. Biostratigraphy and paleoceanographic potential of the Cretaceous planktic foraminifera Heterohelicidae. [Ph.D. thesis]. Centrale Huisdrukkerij Vrije Univ., Amsterdam.

Pessagno, E. A., Jr., 1977. Upper Cretaceous planktonic foraminifera from the western Gulf Coastal Plain. Palaeontograph. Am., 5:245445.

Plummer, H. J., 1926. Foraminifers from the Midway Formation in Texas. Texas Univ. Bull., 2644.

Robaszynski, F., and Caron, M. (Coordinators), 1979. Atlas de Foraminifères Planctoniques du Crétacé Moyen (vols. 1 and 2). Cah. Micropaleontol.

Robaszynski, F., Caron, M., Gonzalez-Donoso, J.-M., and Wonders, A.A.H., 1984. Atlas of Late Cretaceous planktonic foraminifera. Rev. Micropaleontol., 26:145-305.

Sigal, J., 1952. Aperçu stratigraphique sur la micropaléontologie du Crétacé. Monogr. Reg. Int. Geol. Congr., 19th, Ser. I, 26:1-47.

Tappan, H., 1940. Foraminifera of the Grayson Formation of northern Texas. J. Paleontol., 14:93-167.

White, M. P., 1928. Some index foraminifera of the Tampico Embayment of Mexico (part 2). J. Paleontol., 2:280-317.

Wonders, A.A.H., 1978. Phylogeny, classification and biostratigraphic distribution of keeled Rotaliporinae. Proc. K. Ned. Akad. Wet., Ser. B, 81:113-143.

1979. Middle and Late Cretaceous pelagic sediments of the Umbrian Sequence in the Central Apennines. Proc. K. Ned. Akad. Wet., Ser. B, 86:171-605.

1980. Middle and Late Cretaceous planktonic foraminifera of the western Mediterranean area. Utrecht Micropaleontol. Bull., 64:1-157.

Wright, C. W., and Apthorpe, M., 1977. Planktonic foraminiferids from the Maastrichtian of the Northwest Shelf, Western Australia. J. Foraminiferal Res., 7:668-641.

Date of initial receipt: 19 June 1990

Date of acceptance: 1 April 1991

Ms 122B-160 
APPENDIX

Samples Studied

\begin{tabular}{|c|c|c|c|c|c|c|c|}
\hline $\begin{array}{l}\text { Core, section, } \\
\text { interval }(\mathrm{cm})\end{array}$ & $\begin{array}{l}\text { Depth } \\
\text { (mbsf) }\end{array}$ & $\begin{array}{l}\text { Core, section, } \\
\text { interval }(\mathrm{cm})\end{array}$ & $\begin{array}{l}\text { Depth } \\
\text { (mbsf) }\end{array}$ & $\begin{array}{l}\text { Core, section, } \\
\text { interval }(\mathrm{cm})\end{array}$ & $\begin{array}{l}\text { Depth } \\
\text { (mbsf) }\end{array}$ & $\begin{array}{l}\text { Core, section, } \\
\text { interval }(\mathrm{cm})\end{array}$ & $\begin{array}{l}\text { Depth } \\
\text { (mbsf) }\end{array}$ \\
\hline 122-761B- & & $47 X-1,60-62$ & 593.12 & $66 \mathrm{X}-1,60-62$ & 765.62 & $18 \mathrm{X}-\mathrm{CC}$ & 351.50 \\
\hline $22 X-3,60-62$ & 183.32 & $47 X-4,66-68$ & 596.18 & $66 \mathrm{X}-2,60-62$ & 767.12 & $19 \mathrm{X}-\mathrm{CC}$ & 361.00 \\
\hline $22 X-5,60-62$ & 186.32 & $48 X-4,55-57$ & 607.07 & $69 X-2,60-62$ & 782.12 & 20X-CC & 370.50 \\
\hline $23 X-1,60-62$ & 189.82 & $50 \mathrm{X}-1,60-62$ & 621.62 & $70 \mathrm{X}-1,64-66$ & 785.66 & $21 X-1,110-112$ & 371.62 \\
\hline $23 X-2,57-59$ & 191.29 & $51 X-1,60-62$ & 631.12 & $71 X-1,86-88$ & 790.88 & $22 \mathrm{X}-1,109-111$ & 381.11 \\
\hline $24 X-1,56-58$ & 199.28 & $52 X-4,60-62$ & 645.12 & $72 X-2,66-68$ & 797.18 & 23X-CC & 399.00 \\
\hline $24 \mathrm{X}-2,63-65$ & 200.85 & $53 \mathrm{X}-1,60-62$ & 650.12 & $73 X-1,60-62$ & 800.12 & $24 \mathrm{X}-1,107-109$ & 400.09 \\
\hline $24 X-3,60-62$ & 202.32 & $53 X-4,60-62$ & 654.62 & $73 X-2,60-62$ & 801.62 & $24 \mathrm{X}-2,107-109$ & 401.59 \\
\hline $24 X-4,61-63$ & 203.83 & $54 \mathrm{X}-1,60$ & 659.60 & $74 \mathrm{X}-3,41-43$ & 807.93 & $24 X-3,107-109$ & 403.09 \\
\hline $25 \mathrm{X}-1,59-62$ & 208.82 & $54 X-4,60$ & 664.10 & $75 X-1,71-72$ & 810.22 & $24 X-4,107-109$ & 404.59 \\
\hline $25 X-2,57-60$ & 210.30 & $55 \mathrm{X}-1,60-62$ & 669.12 & $75 X-1,114-115$ & 810.62 & $24 X-5,107-109$ & 406.09 \\
\hline $26 \mathrm{X}-2,60-62$ & 219.82 & $58 \mathrm{X}-1,60-62$ & 697.62 & $78 \mathrm{X}-1,56-58$ & 831.08 & $26 \mathrm{X}-\mathrm{CC}$ & 427.50 \\
\hline $27 X-1,66-68$ & 227.88 & $58 X-4,60-62$ & 702.12 & & & $27 \mathrm{X}-1,109-111$ & 428.61 \\
\hline $27 X-2,86-71$ & 229.41 & $59 \mathrm{X}-1,70-72$ & 707.22 & $a_{122-763 B-}$ & & $27 \mathrm{X}-\mathrm{CC}$ & 437.00 \\
\hline \multirow[t]{2}{*}{$27 X-3,64-66$} & 230.86 & $59 X-3,60-62$ & 710.12 & $8 X-2,18-20$ & 248.70 & $28 X-2,112-114$ & 439.64 \\
\hline & & $60 X-1,43-44$ & 716.44 & $9 \mathrm{X}-1,109-111$ & 257.61 & 28X-CC & 446.50 \\
\hline $122-762 \mathrm{C}$. & & $60 X-2,40-43$ & 718.12 & $10 \mathrm{X}-1,109-111$ & 267.11 & $29 \mathrm{X}-1,109-111$ & 447.61 \\
\hline $43 \mathrm{X}-1,35-37$ & 554.87 & $61 X-1,65-67$ & 726.17 & $11 X-1,109-111$ & 276.61 & 29X-CC & 456.00 \\
\hline $43 X-1,144-146$ & 555.96 & $61 X-2,60-62$ & 727.62 & $11 X-5,110-112$ & 282.62 & $30 \mathrm{X}-3,108-110$ & 460.10 \\
\hline $44 X-1,60-62$ & 564.62 & $62 X-1,57-60$ & 735.60 & $13 \mathrm{X}-1,109-111$ & 295.61 & $32 X-2,109-111$ & 477.61 \\
\hline $44 X-4,60-62$ & 569.12 & $62 X-3,60-62$ & 738.62 & $14 \mathrm{X}-1,119-121$ & 305.21 & $33 \mathrm{X}-1,109-111$ & 485.61 \\
\hline $45 X-1,60-62$ & 574.12 & $63 \mathrm{X}-1,60-62$ & 745.12 & $15 X-3,110-112$ & 317.62 & $34 X-4,109-111$ & 499.61 \\
\hline $45 \mathrm{X}-3,60-62$ & 577.12 & $63 X-2,60-62$ & 746.62 & $15 \mathrm{X}-\mathrm{CC}$ & 323.00 & $35 \mathrm{X}-3,109-112$ & 507.62 \\
\hline
\end{tabular}

${ }^{\text {a }}$ Samples were screened only on the presence and absence of zonal markers. Evidence from core-catcher samples collected during shipboard analysis, as presented in Haq, von Rad, O'Connell, et al. (1990), was taken into account as well. 

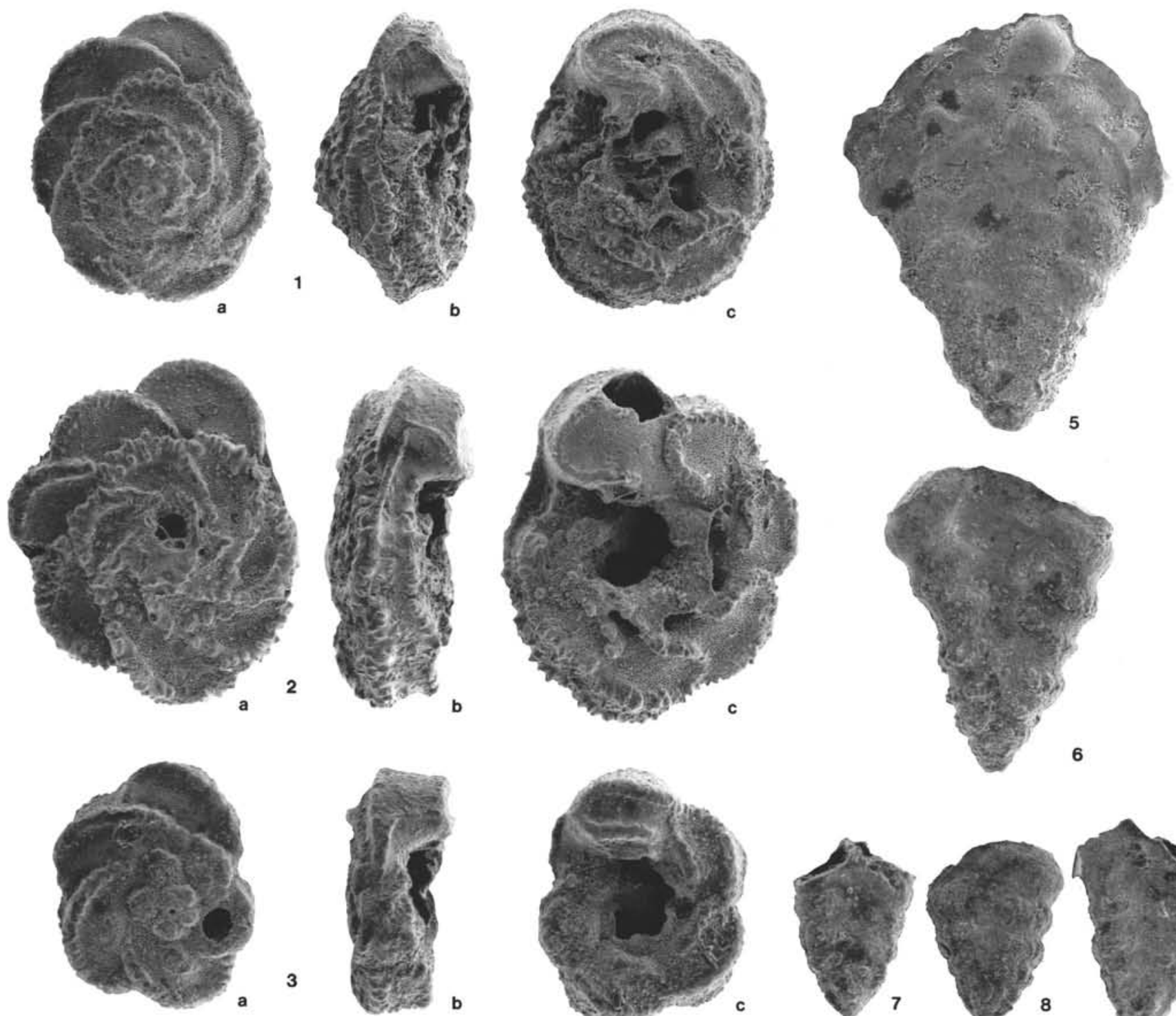

3
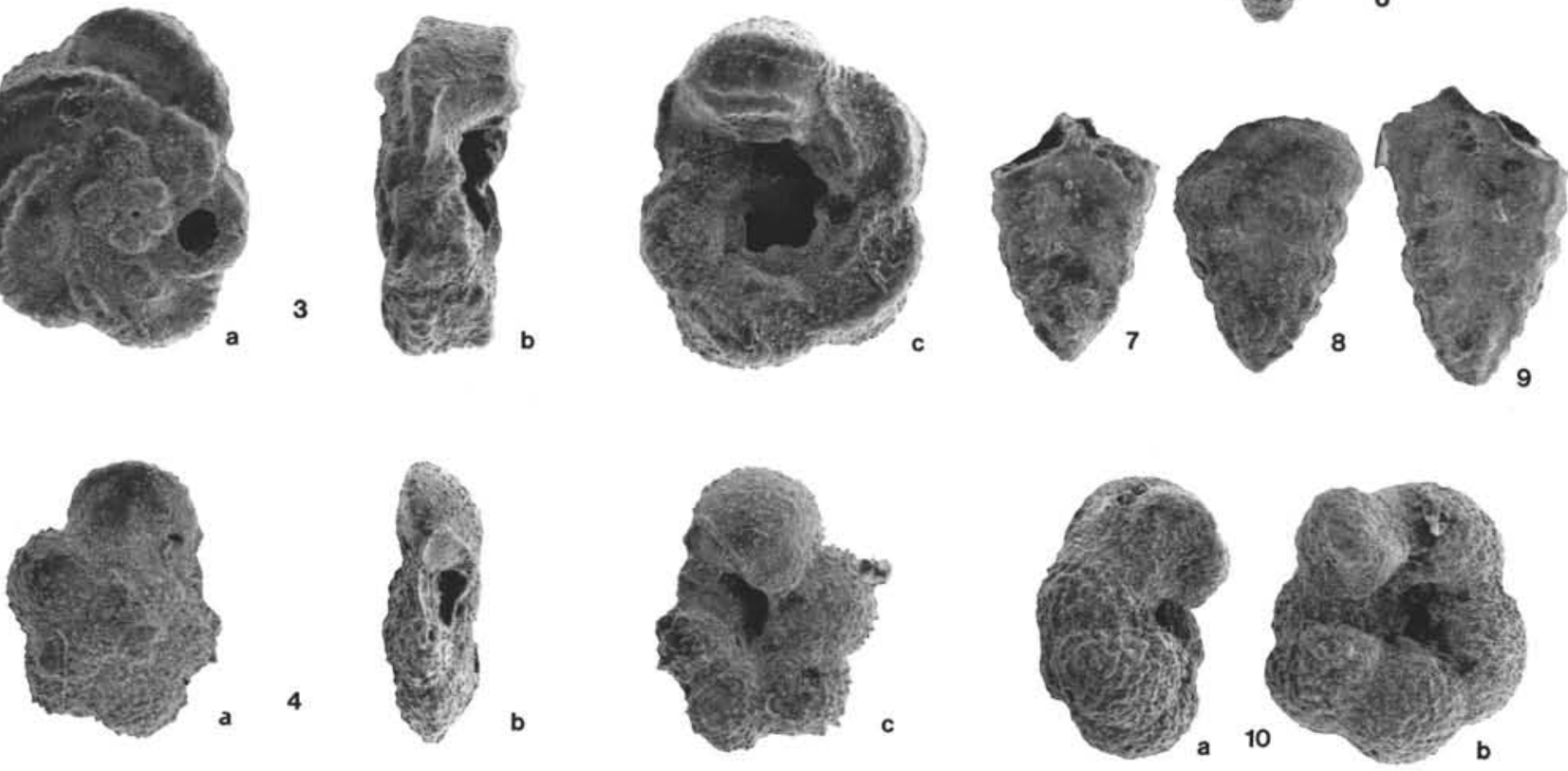

Plate 1. All magnifications 72×. 1a-c. Globotruncana arca, Sample 122-761B-25X-1, 59-62 cm (208.82 m below seafloor [mbsf]). 2a-c, 3a-c. Globotruncana linneiana, Sample 122-761B-25X-1, 59-62 cm (208.82 mbsf). 4a-c. Globotruncanella pshadae, Sample 122-761B-25X-1, 59-62 cm (208.82 mbsf). 5, 6. Gublerina cuvillieri, Sample 122-761B-24X-4, 61-63 cm (203.83 mbsf). 7-9. Heterohelix rajagopalani, Sample 122-761B25X-1, 59-62 cm (208.82 mbsf). 10a, 10b. Rugoglobigerina rugosa, Sample 122-762C-53X-4, 60-62 cm (650.12 mbsf). 

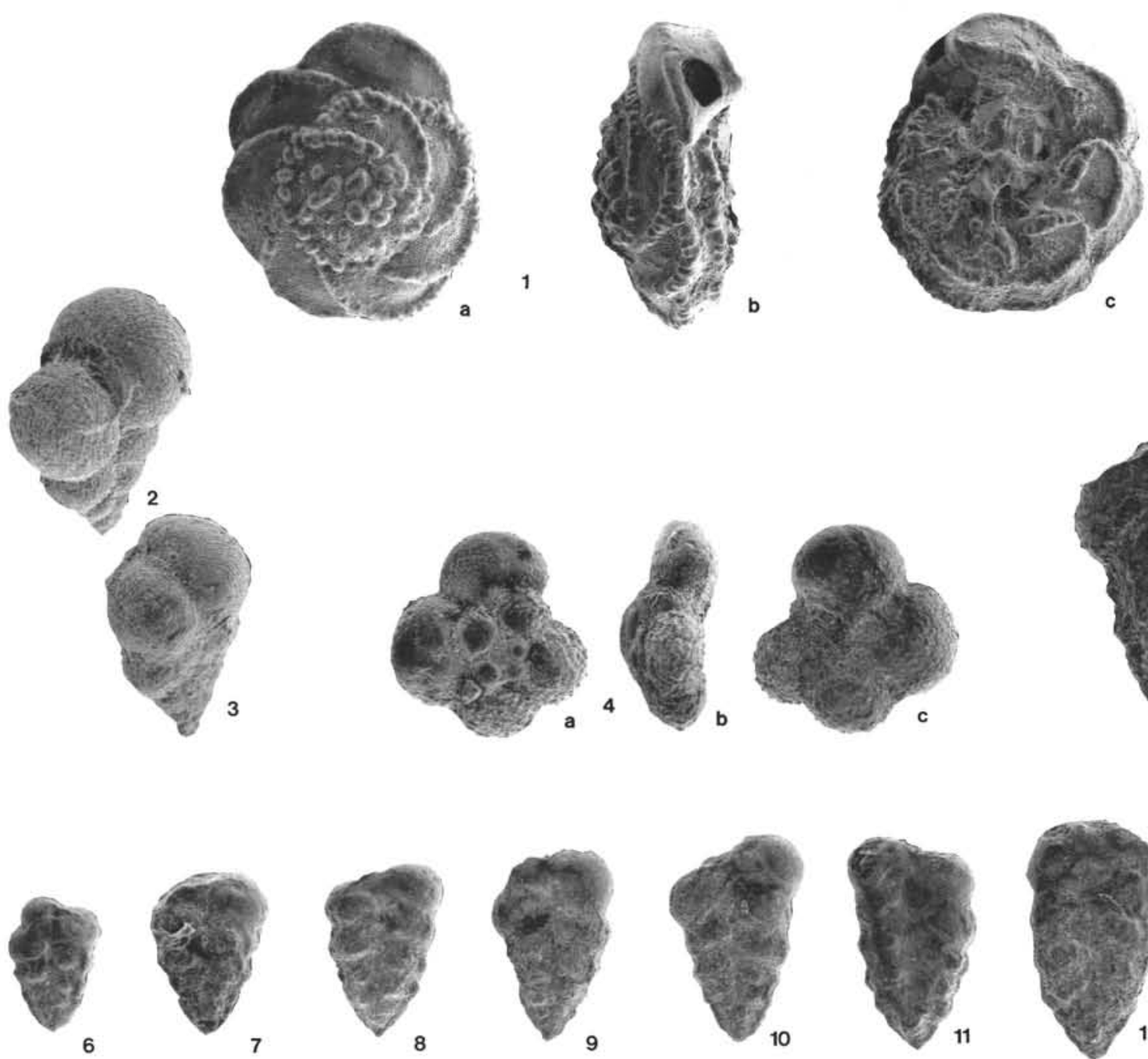

8
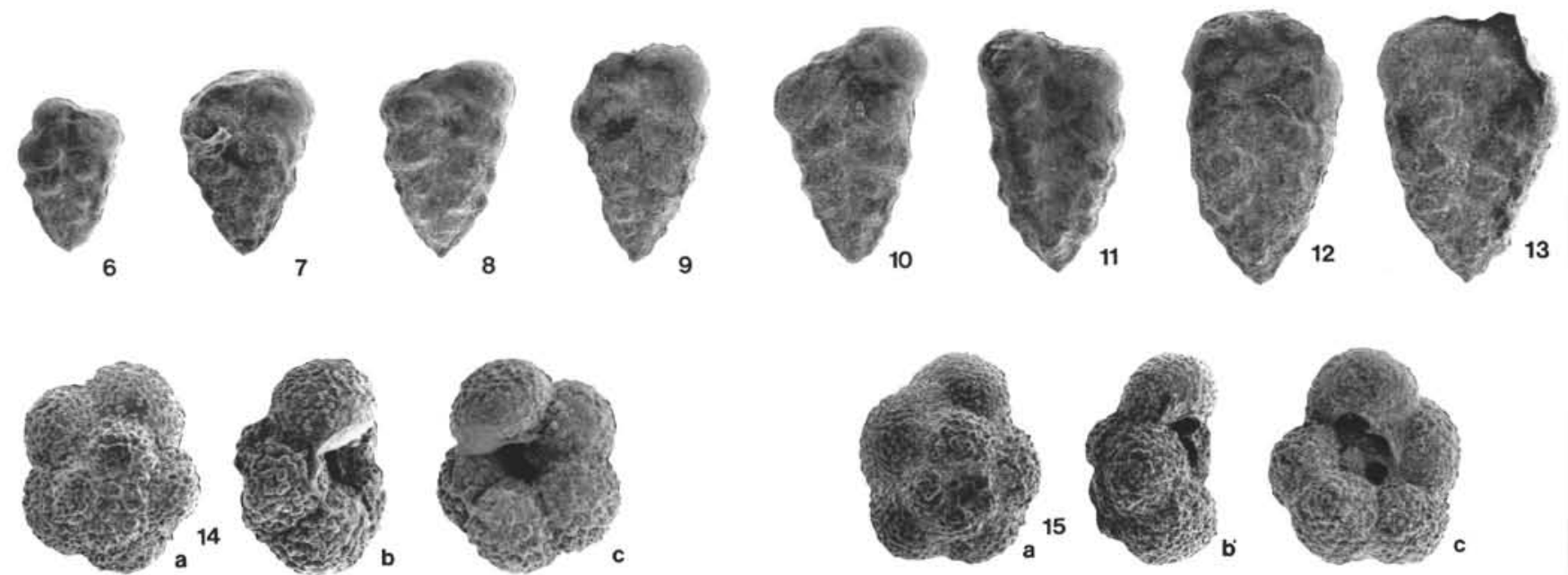

Plate 2. All magnifications $72 \times$. 1a-c. Globotruncana arca, Sample $122-762 \mathrm{C}-51 \mathrm{X}-4,60-62 \mathrm{~cm}(635.62 \mathrm{mbsf})$. 2, 3. Pseudotextularia nuttalli, Sample 122-762C-51X-4, 60-62 cm (635.62 mbsf). 4a-c. Globotruncanella havanensis, Sample 122-762C-51X-4, 60-62 cm (635.62 mbsf). 5-13. Heterohelix rajagopalani, Sample 122-762C-51X-4, 60-62 cm (635.62 mbsf). 14a-c, 15a-c. Rugoglobigerina rugosa, Sample 122-763B-9X-1, $109-111 \mathrm{~cm}(257.61 \mathrm{mbsf})$. 

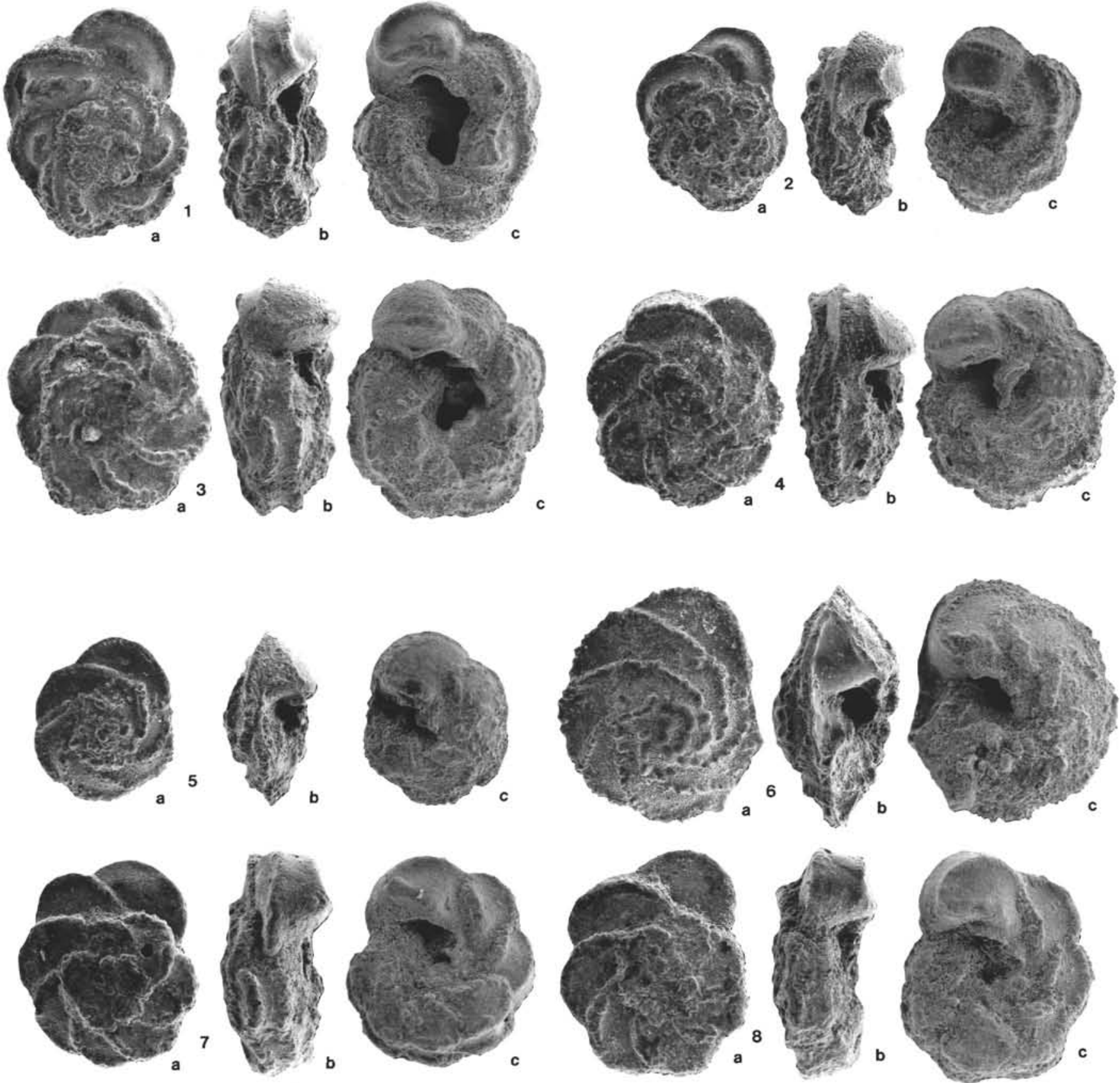

Plate 3. All magnifications 72×. 1a-c, 2a-c. Globotruncana bulloides, Sample 122-763B-9X-1, 109-111 cm (257.61 mbsf). 3a-c, 4a-c. Globotruncana ventricosa, Sample 122-763B-9X-1, 109-111 cm (257.61 mbsf). 5a-c, 6a-c. Globotruncanita stuartiformis, Sample 122-763B9X-1, 109-111 cm (257.61 mbsf). 7a-c, 8a-c. Marginotruncana pseudolinneiana, Sample 122-763B-20X-1, 109-111 cm (362.11 mbsf). 

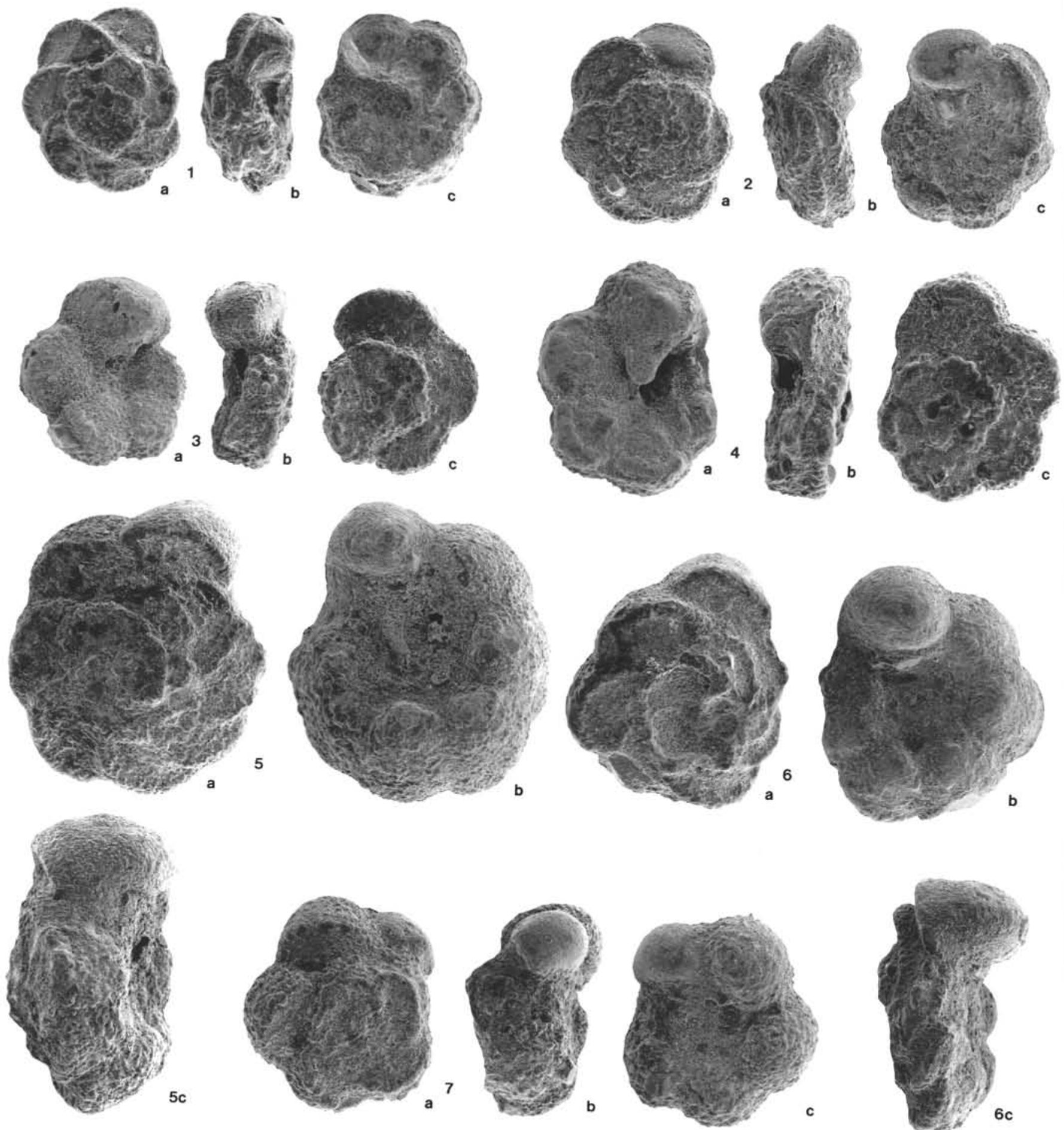

Plate 4. All magnifications 72×. 1a-c, 2a-c. Dicarinella imbricata, Sample 122-763B-21X-1, 110-112 cm (371.61 mbsf). 3a-c, 4a-c. Falsotruncana maslakovae, Sample 122-763B-20X-1 109-111 cm (362.11 mbsf). 5a-c, 6a-c. Marginotruncana marianosi, Sample 122-763B21X-1, 110-112 cm (371.61 mbsf). 7a-c. Helvetoglobotruncana helvetica, Sample 122-763B-21X-1, 110-112 cm (371.61 mbsf). 

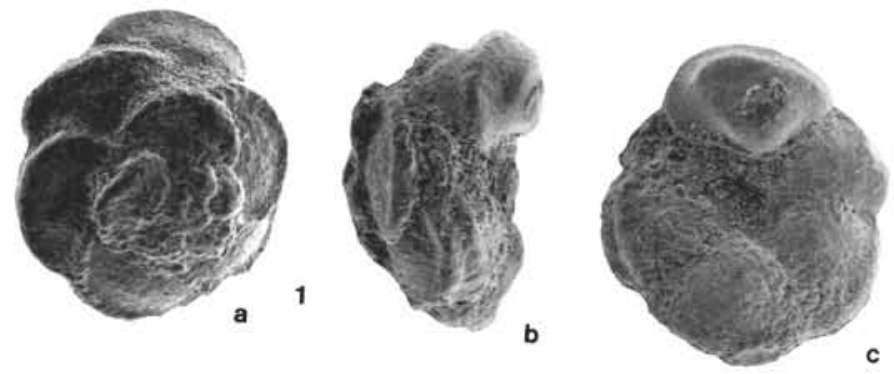

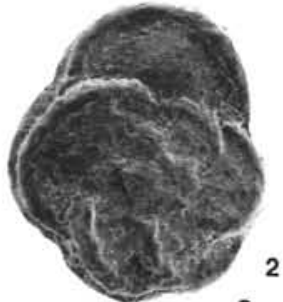

a
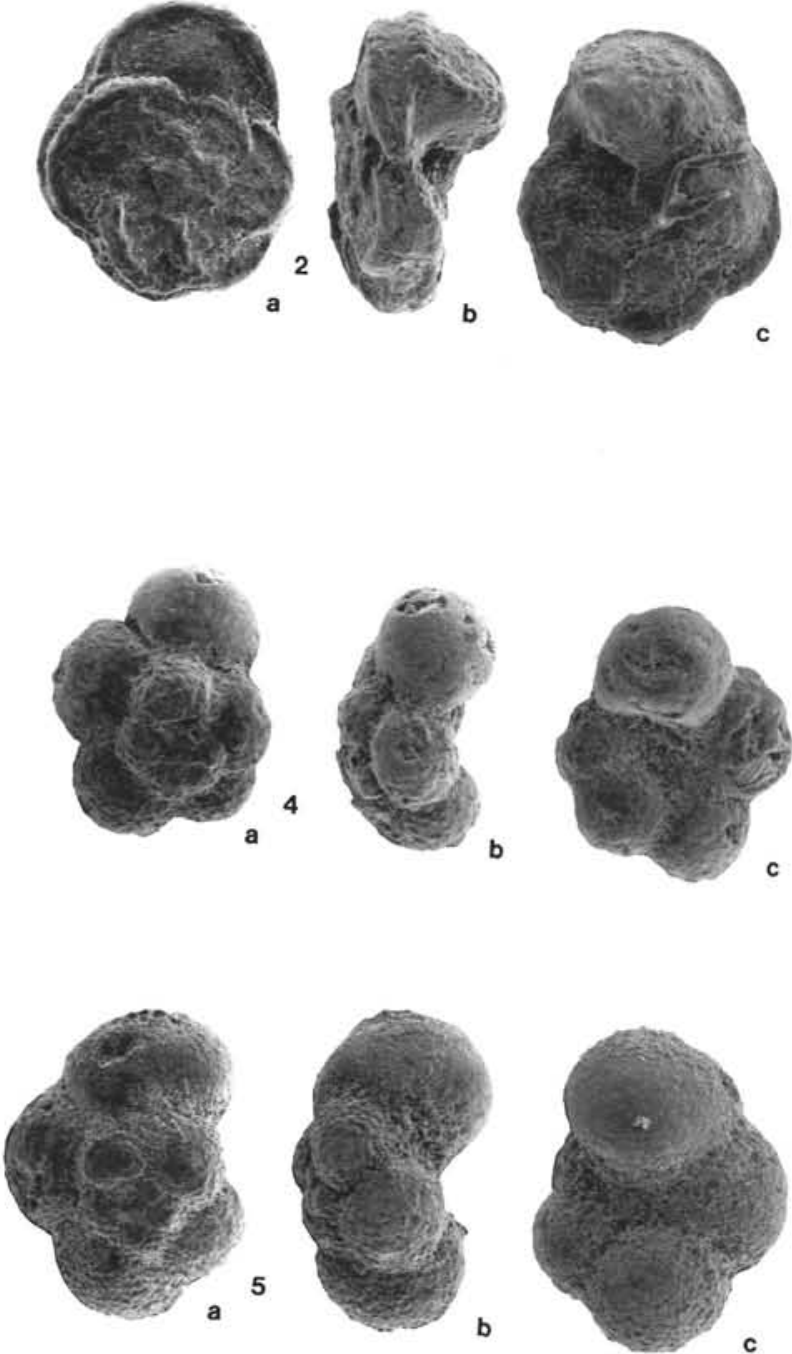
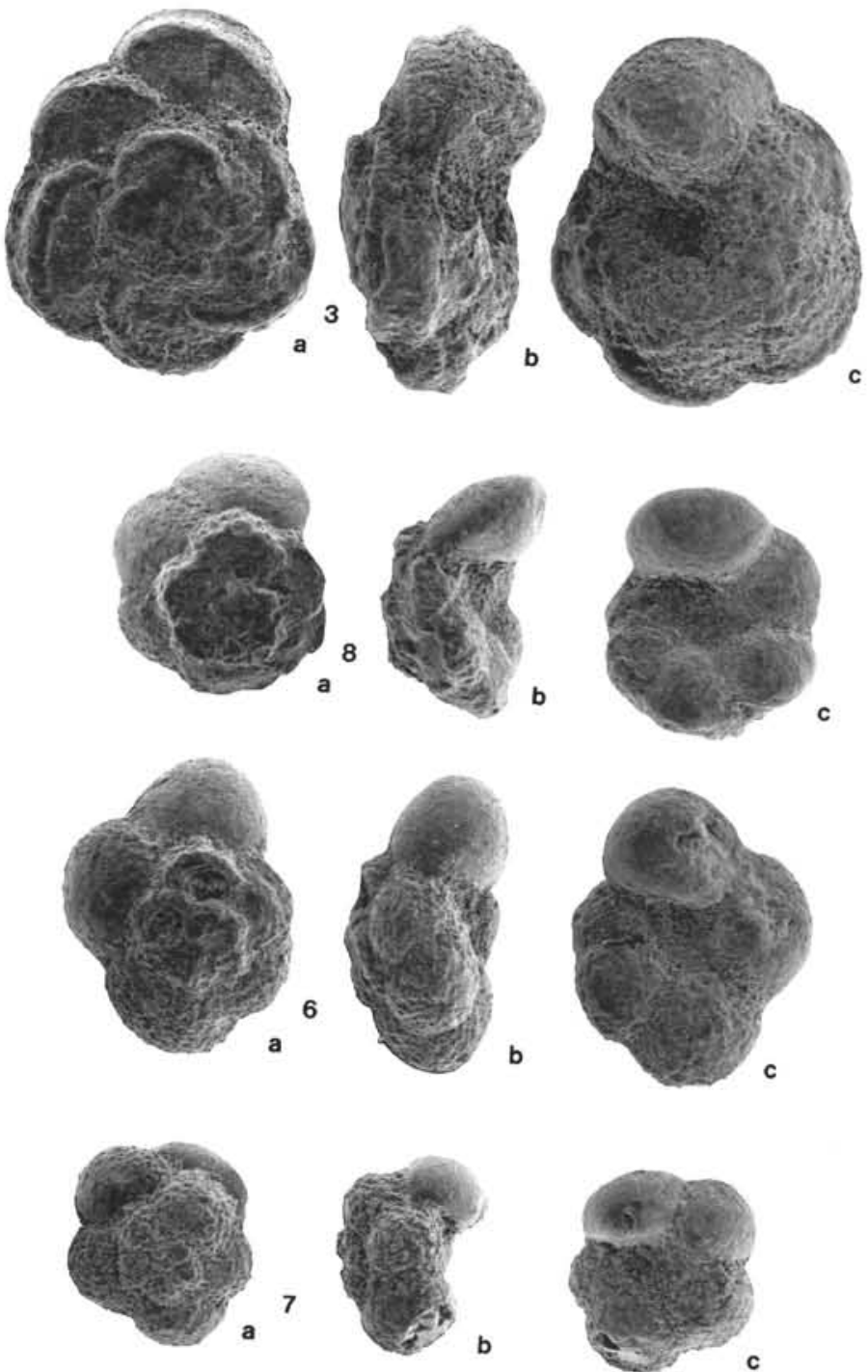

Plate 5. All magnifications $72 \times$. 1a-c. Dicarinella imbricata, Sample 122-763B-22X-1, 109-111 cm (381.11 mbsf). 2a-c, 3a-c. Dicarinella hagni, Sample 122-763B-22X-1, 109-111 cm (381.11 mbsf). 4a-c through 7a-c. Whiteinella archaeocretacea, Sample 122-763B-22X-1, 109-111 cm (381.11 mbsf). 8a-c. Praeglobotruncana gibba, Sample 122-763B-22X-1, 109-111 cm (381.11 mbsf). 